\title{
Effect of Balance Dose of Fertilizers and Irrigation on Yield and Yield Component of Wheat Cultivar
}

\author{
Saurabh Sharma*, Ravindra Korake and Rohini Bharad \\ Deendayal Research Institute, Krishi Vigyan Kendra, Ambajogai District-Beed, \\ Maharashtra, India \\ *Corresponding author
}

\section{Keywords}

No. of tillers,

Percentage of effective tillers, yield and $\mathrm{B}: \mathrm{C}$ ratio

Article Info

Accepted:

25 March 2021

Available Online:

10 April 2021

\section{A B S T R A C T}

The study has revealed that there is a sufficient potential increasing wheat production in Madhya Pradesh by provides quality seeds of improved variety, balance dose of fertilizers and awareness of irrigation schedules of wheat crop. Under demonstration is a most suitable method for assessing the performance of improved verities of wheat cultivar GW-322, GW-273 and MP-1142 respectively with the existing cultivars LOK-1 and Sujata under different irrigation levels. The results of demonstrations shows a greater impact on farmers face due to significant increase average in crop yield $47.1,60.0,52.6$ and $68.4 \%$ respectively over local check. Which results in not only adopting these varieties in large scale but also some of the farmers have started producing seeds of these improved varieties and maximum yield was found of water loving and fertilizers responsive variety of wheat viz GW-322, GW-273 and MP1142 $(57.8,55.0$ and $52.1 \mathrm{q} / \mathrm{ha})$ respectively under four irrigation at all definable growth stages as compared to less responsible/frequency of irrigation of existing variety of wheat LOK-1 and Sujata (46.2 and $34.0 \mathrm{q} / \mathrm{ha}$ ). And highest B:C ratio was obtained in wheat cultivar GW-322 (1:2.7) followed by GW-273 and MP-1142 under demonstration as compared to traditional variety of wheat Lok-1 and Sujata (1:2.2 and $1: 2.1)$.

\section{Introduction}

Wheat (Triticum aestivum L) is one of the main cereals crops, cultivated to meet great demands of the population for human feeding. It is the most important staple food in India. Rapid increase in wheat consumption outpaced domestic production due to population growth. The area of wheat in this country (29.25 m.ha) an account of production and productivity (85.93 m.tonnes and 2938 $\mathrm{kg} / \mathrm{ha}, 2010-11$ department of Agriculture and cooperation) is very quit low against the variety potential of wheat crop 4500-5500 $\mathrm{kg} / \mathrm{ha}$. Over all Agriculture production from wheat has tended to increase increscent years, but even this is not enough to keep up with population growth and positive outcome. 
Similar to defectively situation was noted in study area of Sehore District of Madhya Pradesh in terms of productivity (2000 kg/ha) as compared to national productivity. There are numerous regions was found for low productivity of wheat crop i.e. seed replacement rate is very poor, Imbalance use of fertilizers $(50 \mathrm{~kg} / \mathrm{ha})$ and improper management of irrigation water due to lack of awareness to irrigation scheduling and other input like improved seeds and balance dose of fertilizers of wheat crop. Therefore, most of the farmers are supplying irrigation on availability of water neither is necessity of crop. Under such circumstances Fertilizer Association of India (New Delhi) has decide to conduct FLD on 50 farmer's field in this districts against the problems by the active participation of IFFCO with technical support of KVK. Because much extensive productive technology is now available this can boost wheat production. But any viable and adoptive technology has not reached to growers accorded by Singh et al., 2004. In such situation KVK develop a package for enhancing the productivity of wheat crop through introduction of improved varieties, balance dose of fertilizers and supply of water as per schedule of wheat crop. To reduce the yield gap between farmers practices and front line demonstration and shows the potential to increase the yield further. Rahim et al., 2007, Wajid et al., (2002) reported that wheat crop produced highest grain yield by applying irrigation at all definable growth stages. Because adequate supply of irrigation water and fertilizers main factors affecting directly the growth and productivity of wheat plant. Water supply as per schedule is limiting factors for crop production it is desirable to obtain higher grain yield. Grain yield was affected by both the magnitude of water deficit and stage growth subjected to deficit. Schneider and Howell 1997 and Awad et al., 2000 reported that increase irrigation of soil water amounts from zero to $100 \%$ significantly increased grain yield and its components. Hence an experiment was conducted to study growth, yield, B: C ratio and fertilizer use efficiency of wheat cultivar under balance dose of fertilizers and different irrigation scheduling.

\section{Materials and Methods}

Preliminary survey of farmers field for diagnose to problems of low productivity of wheat crop through discussion and group meeting. After surveyed was found problems low yield of wheat crop due to lack of awareness to improved technology and variety. A field experiment was conducted on five farmers fields of 10 villages for create awareness to improved technology, Variety and irrigation scheduling. Under demonstrations have one acre area with half acre for recommended practices and half acre farmers' practice. Collected soil sample for analysis of individual demonstration plot to work out nutrient requirement. And applied fertilizer on the basis of soil test value in half acre area of recommended practices. The all selected village is characterized medium to deep black soil which had low available nitrogen (250-280 kg N/ha), medium available phosphorus (12-20 $\mathrm{kg} \mathrm{P}_{2} \mathrm{O}_{5} / \mathrm{ha}$ ) and medium to high available potash (196-313 kg $\left.\mathrm{K}_{2} \mathrm{O} / \mathrm{ha}\right)$ and soil $\mathrm{p}^{\mathrm{H}} 6.8$ to 7.8. The front line demonstration was laid out RBD design with observation of three replication. The study have indicated that the replacement of existing variety, imbalance use of fertilizer and irrigation management as per availability of water by improved variety GW-322, GW-273 and MP-1142, use of balance dose of fertilizers as per soil test value and irrigation management as per schedule of wheat crop. Application of complex fertilizers (N:P:K 10:26:26)@100 kg Plus urea @ $80 \mathrm{~kg}$ and Zinc sulphate $5 \mathrm{~kg}$ /acre and seed treated with Azotobactore and PSB @ $5 \mathrm{~g} / \mathrm{kg}$ seeds). Full dose of complex fertilizers applied in field at 
the time of sowing. And remain dose of nitrogen through urea broad cast in wheat crop as two equal split applications at standing crop. Data were collected from both the demonstration and farmers practices with the help of personal contact and observations on yield and yield component was also recorded at the physiological maturity and threshing time.

The on farm primary data was analyzed by percentage return to fertilizers in term of yield, Fertilizers use efficiency on economically and interaction impact of grain yield was calculated according to (Baligar et al., 2001 and Singh et al., 2007).

Harvest index (HI) is the ratio of grain yield to biological yield, which a measure of the efficiency of the plant when accumulating assimilates in the organs of economic significance (Donald 1968).

\section{Results and Discussion}

Levels of use and gap in adoption of improved varieties of wheat with balance dose of fertilizers.

Farmers are generally use local varieties due to quality seed of improved varieties are not easily available and lack of awareness to their characters (Table.1). Very few farmers were able to arrange improved variety of seed. And they followed broadcast method of sowing against the recommended line sowing with seed cum fertidril.

Therefore, they applied higher seed rate than the recommendation. And use of imbalance (lower) dose of fertilizer was applied against the recommended dose of fertilizers. Further full gap was observed in case of improved varieties, seed treatment, irrigation as per schedule and weed management of wheat crop.

\section{Growth and yield parameter}

Among the five varieties evaluated maximum plant height $(125 \mathrm{~cm})$ was recorded in exiting variety of wheat cultivar Sujata (Table -2), differing significantly from rest of the tested varieties. Number of tillers/plant and percentage of effective tillers, were significantly higher in the wheat cultivar GW322 (8.0/plant and 87.5 percent) respectively fallowed by GW-272 (8 and 87\%) with the exiting variety of wheat Sujata \& Lok-1, while the lowest number of tillers/plant and percentage of effective tillers was recorded in wheat cultivar Sujata (7.0/plant and $76 \%$ ). Further more number of tillers/unit area $\left(1 \mathrm{~m}^{2}\right)$, ear length and their width recorded in different varieties differed significantly except GW-273 and significantly higher harvest index was recorded in wheat cultivar Sujata and Lok-1. Earlier studies in wheat cultivar indicated that higher grain yield and net return were found to be associated with more number of effective tillers, ear length, ear width and test weight (Ambika et al., 2002 and Samonta et al., 2007).

\section{Grain and Straw yield}

The pooled mean analysis of wheat varieties for grain yield indicated that the overall performance of GW-322 was significantly better with higher yield (48.3 q/ha) over the existing variety Sujata $(33.7 \mathrm{q} / \mathrm{ha})$ with an additional yield of $14.6 \mathrm{q} / \mathrm{ha}$ and $30.2 \%$ increase. The straw yield of the variety was significantly lower in wheat cultivar MP-1142 (54.7 q/ha) than GW-322 (64.3 q/ha) indicated that the translocation of photosynthates was more towards economic parts. Tunio et al., (2002) also observed that variety with more productive tillers/plant, number of grains /ear, ear length and their width recorded higher yield. The enhancement in yield of different wheat cultivar 19.4 to 30.2 percentages was recorded in recommended practices over 
farmer's practices. Due to balance dose of fertilizer with improved variety, because its dose play vital role in photosynthesis and proper uptake of nutrients as per crop demand. This ultimately resulted in increase photosynthetic activity better growth owing to enzyme activation. Consequently better expression of all these yield and yield attributes resulted increased grain and straw yield of wheat these findings are in agreement with those of Dubey and Sharma 1996, Manna et al., 2003, Aulakh and Malhi 2005 and Behera et al., 2007.

\section{Grain Straw ratio}

The maximum grain and straw ratio was recorded in existing varieties of wheat Sujata as compared to bread wheat cultivar GW-322, GW-273 etc. While maximum dry matter production was recorded in bread wheat cultivar GW-322 fallowed by GW-273 as compared to existing variety of Sujata and Lok-1. Because high yielding semi dwarf varieties is basically known to more water and fertilizers responsible.

Therefore, appropriate supply of fertilizers with efficient water supply during all growth stage increases the leaf area of the crop enable it to intercept most of the incoming radiation through increasing leaf production and expansion rate that effect of increase interception of photo-synthetically active radiation (PAR) by photosynthetic organ.

And conversion of the intercepted radiation in to dry matter and more portioning of that dry matter into economic grain yield as expressed harvest index and consequently the increase maximum dry matter production (Pal et al., 2001 and Moragues et al., 2006). Insufficient availability of NPK to wheat plant results in low dry matter production and significantly reduced profit compared to properly fertilize with irrigated crop.

\section{Effect of irrigation management on varietal performance}

The crop was received irrigation based on availability neither is necessity. Its due to yield is more fluctuate between water loving variety and limited irrigated variety due to less response of yield/frequency of irrigation. While farmers are supply of water based on availability neither is necessity due to lack of awareness of irrigation scheduling of wheat crop. In such situation observation was recorded at harvesting stage i.e. Yield and yield attributes, cost benefit ratio under different irrigation schedule i.e. Crown root initiation (CRI), maximum tillering, boot stage and milking stage. Maximum yield and yield attributes was noted in wheat cultivar i.e. GW322, No. of tillers $/ \mathrm{m},{ }^{2}$ Percentage of effective tillers, No. of grains/ears, Test weight, grain yield $\mathrm{q} / \mathrm{ha} \quad(8.0,96.0,43.5,37.8$ and 57.8) respectively fallowed by GW-273 (8.0,95, $352,41.8,37.4$ and 55.0) as compared to existing variety LOK-1 and Sujata (7.0, 80.0,35037.4 36.6, 46.2 and 6.0, 80, 300, $37.8,34.0$ ) respectively (Table -3). And slightly low to similarly yield was found in all cultivar GW-322,GW-273,MP-1142,LOK-1 and Sujata (57.0,53.2,52.1,45.8 and $32.8 \mathrm{q} / \mathrm{ha})$ respectively of wheat crop with three irrigation irrespective of time of application as compared to two irrigation GW-322, GW273,MP-1142,LOK-1 and Sujata (50, 48.9,45.6,38.2 and 31.2 q/ha) Pal et al., 1996, Pal et al., 2001 also observed yield reduction in wheat with irrigation compared with the crop raised with four irrigation. Wheat receiving three irrigations at maximum tillering, booting and milk stage gave similar to lower grain and straw yield compared with four irrigation. Maximum dry matter accumulation though out the crop growth period was recorded in the crop received four irrigation at (Crown root initiation (CRI), maximum tillering, boot stage and milking stage) with balance dose of fertilizers. 
Table.1 Level of use and gap in adoption of improved varieties of wheat with balance dose of fertilizers

\begin{tabular}{|c|c|c|c|}
\hline $\begin{array}{c}\text { Crop } \\
\text { Operations }\end{array}$ & Recommended technologies & Existing technologies & Gap* \\
\hline Variety & MP-1142.GW-273 and GW-322 & Sujata, C-306 and Lok-1 & Full gap \\
\hline $\begin{array}{c}\text { Land } \\
\text { preparation }\end{array}$ & One cultivator ploughing and 3 ploughings & $\begin{array}{c}\text { One cultivator ploughing and } 3 \\
\text { ploughings }\end{array}$ & Nil \\
\hline Seed rate & $\begin{array}{c}\text { @ } 100 \mathrm{Kg} / \mathrm{ha} \text { ( } \mathrm{MP}-1142 . \mathrm{GW}-273 \text { and GW-322with line } \\
\text { sowing) }\end{array}$ & $\begin{array}{c}\text { @ 140-50 Kg/ha (broadcast or } \\
\text { withoutline sowing) }\end{array}$ & $\begin{array}{l}\text { Use of higher seed rate } \\
\text { and avoid line sowing }\end{array}$ \\
\hline $\begin{array}{c}\text { Seed } \\
\text { treated }\end{array}$ & @ 2 g Carbendazim with @1 g Thaiaram/kg seed & $\begin{array}{l}\text { No use of fungicides for seed } \\
\text { treatment }\end{array}$ & Full gap \\
\hline Fertiliser & $\begin{array}{c}\text { 100:60:40 Kg/ha NPK with dual inoculation of } \\
\text { Azotobactore and PSB @ 10g/ Kg seed }\end{array}$ & $\begin{array}{l}95 \mathrm{Kg} / \mathrm{ha} \text { NPK without } \\
\text { inoculation of culture }\end{array}$ & $\begin{array}{l}105 \mathrm{Kg} / \mathrm{ha} \mathrm{NPK} \text {, and } \\
\text { No inoculation of } \\
\text { culture }\end{array}$ \\
\hline Weeding & Weed control through chemicali.e 2,4-D and sulfosulfuron & No weed control & $\begin{array}{l}\text { Chemical weeding is } \\
\text { not done( Full Gap) }\end{array}$ \\
\hline Irrigation & $\begin{array}{l}\text { Applying irrigation at all definable growth stages i.e. Crown } \\
\text { root initiation, maximum tillering, boot stage and milking } \\
\text { stage }\end{array}$ & $\begin{array}{l}\text { Applying irrigation based on } \\
\text { availability neither is necessity } \\
\text { as per definable growth stages }\end{array}$ & Full gap \\
\hline
\end{tabular}

Table.2 Performance of wheat varieties and their comparatively study in similar situation

\begin{tabular}{|c|c|c|c|c|c|c|c|c|c|c|c|c|c|c|}
\hline Varieties & $\begin{array}{c}\text { Plant } \\
\text { height } \\
\text { (cm) }\end{array}$ & $\begin{array}{c}\text { No. of } \\
\text { tillers/p } \\
\text { lant }\end{array}$ & $\begin{array}{l}\text { No. of } \\
\text { effective } \\
\text { tillers }\end{array}$ & $\begin{array}{l}\text { Percent } \\
\text { age of } \\
\text { effective } \\
\text { tillers }\end{array}$ & $\begin{array}{c}\text { Total } \\
\text { no. of } \\
\text { tillers/ } \\
\text { m2 }\end{array}$ & $\begin{array}{c}\text { Ear } \\
\text { length } \\
\text { (cm) }\end{array}$ & $\begin{array}{c}\text { Ear } \\
\text { width } \\
(\mathrm{cm})\end{array}$ & $\begin{array}{c}\text { No. } \\
\text { grain } \\
\text { s/ear }\end{array}$ & $\begin{array}{c}\text { Test } \\
\text { wt (g) }\end{array}$ & $\begin{array}{c}\text { Grain } \\
\text { yield } \\
\text { g/m2 }\end{array}$ & $\begin{array}{c}\text { Straw } \\
\text { yield/ } \\
\text { m2 }\end{array}$ & $\begin{array}{c}\text { Grain } \\
\text { Yield } \\
\text { q/ha }\end{array}$ & $\begin{array}{c}\text { Straw } \\
\text { yield } \\
\text { q/ha }\end{array}$ & $\begin{array}{c}\text { Grain } \\
\text { straw } \\
\text { ratio }\end{array}$ \\
\hline MP-1142 & 87.0 & 7.5 & 6.5 & 86 & 322 & 11.3 & 1.4 & 40.0 & 36 & 411.8 & 547.7 & 41.8 & 54.7 & 1.3 \\
\hline GW-272 & 90 & 8.0 & 7.0 & 87 & 352 & 12.0 & 1.6 & 42 & 37 & 478.6 & 636.5 & 47.8 & 63.6 & 1.3 \\
\hline GW-322 & 87.5 & 8.0 & 7.0 & 87.5 & 352 & 11.0 & 1.6 & 43 & 36.5 & 483.4 & 642.9 & 48.3 & 64.3 & 1.3 \\
\hline Sujata & 125 & 6.5 & 5.0 & 76 & 325 & 7.6 & 1.4 & 34.6 & 39 & 337.4 & 597.2 & 33.7 & 59.7 & 1.8 \\
\hline Lok-1 & 90.6 & 7.0 & 7.0 & 78 & 343 & 7.9 & 1.4 & 41.6 & 37 & 414.8 & 580.7 & 41.5 & 58.7 & 1.4 \\
\hline
\end{tabular}


Table.3 Effect of irrigation management on varietal performance at different stages

\begin{tabular}{|c|c|c|c|c|c|c|c|c|c|}
\hline Variety & $\begin{array}{c}\text { No of } \\
\text { irrigation }\end{array}$ & $\begin{array}{c}\text { No of Tillers/ } \\
\text { plant }\end{array}$ & $\begin{array}{c}\text { No. of effective } \\
\text { tiller/plant }\end{array}$ & $\begin{array}{l}\text { Percentage of } \\
\text { effective tillers }\end{array}$ & $\begin{array}{l}\text { Total No. of } \\
\text { tillers } / \mathrm{m}^{2}\end{array}$ & $\begin{array}{c}\text { No. of } \\
\text { grains/ear }\end{array}$ & $\begin{array}{c}\text { Test } \\
\text { wt.(g) }\end{array}$ & $\begin{array}{c}\text { Grain yield } \\
\left(\mathrm{g} / \mathrm{m}^{2}\right)\end{array}$ & $\begin{array}{c}\text { Grain yield } \\
\text { (q/ha) }\end{array}$ \\
\hline \multirow{4}{*}{$\begin{array}{l}\text { MP- } \\
1142\end{array}$} & CRI & 5.0 & 4.0 & 80 & 220 & 34 & 34.6 & 258.8 & 25.88 \\
\hline & MT & 8.0 & 7.5 & 93.7 & 330 & 38 & 36.4 & 456.4 & 45.6 \\
\hline & BS & 8.0 & 7.5 & 93.7 & 330 & 42 & 37.2 & 515.2 & 51.6 \\
\hline & MS & 8.0 & 7.5 & 93.7 & 330 & 42 & 37.6 & 521.1 & 52.1 \\
\hline \multirow[t]{4}{*}{ GW-322 } & CRI & 5.1 & 4.0 & 78.4 & 224 & 31 & 34.7 & 241.3 & 24.1 \\
\hline & MT & 8.0 & 7.6 & 95 & 352 & 39 & 36.8 & 505.1 & 50.0 \\
\hline & BS & 8.0 & 7.7 & 96 & 352 & 43.5 & 37.3 & 571.1 & 57.0 \\
\hline & MS & 8.0 & 7.7 & 96 & 352 & 43.5 & 37.8 & 57.8 & 57.8 \\
\hline \multirow[t]{4}{*}{ Gw-273 } & CRI & 5.0 & 4.1 & 82 & 220 & 31 & 34.0 & 231.8 & 23.2 \\
\hline & MT & 8.0 & 7.4 & 92.5 & 352 & 38.5 & 36.1 & 489.2 & 48.9 \\
\hline & BS & 8.0 & 7.5 & 93.7 & 352 & 40.6 & 37.1 & 530.2 & 53.2 \\
\hline & MS & 8.0 & 7.6 & 95 & 352 & 41.8 & 37.4 & 550.2 & 55 \\
\hline \multirow[t]{4}{*}{ Sujata } & CRI & 4.0 & 3.0 & 75 & 220 & 26 & 36.1 & 206.8 & 20.6 \\
\hline & MT & 6.0 & 4.8 & 80 & 300 & 28 & 37.1 & 311.6 & 31.2 \\
\hline & BS & 6.0 & 4.8 & 80 & 300 & 29 & 37.8 & 328.9 & 32.8 \\
\hline & MS & 6.0 & 4.8 & 80 & 300 & 30 & 37.8 & 340.2 & 34.0 \\
\hline \multirow[t]{4}{*}{ LOK-1 } & CRI & 4.4 & 3.4 & 77.2 & 220 & 30.4 & 33.4 & 223.3 & 22.0 \\
\hline & MT & 7.0 & 5.6 & 80 & 350 & 32.3 & 33.8 & 282.2 & 38.2 \\
\hline & BS & 7.0 & 5.6 & 80 & 350 & 37.0 & 35.4 & 458.4 & 45.8 \\
\hline & MS & 7.0 & 5.6 & 80 & 350 & 37.4 & 36.6 & 462.2 & 46.2 \\
\hline
\end{tabular}

Crown root initiation (CRI), maximum tillering, boot stage and milking stage

Table.4 Effect of varietal performance on economic value and Fertilizers use efficiency

\begin{tabular}{|c|c|c|c|c|c|c|c|c|}
\hline Variety & $\begin{array}{c}\text { Yield } \\
(\mathbf{q} / \mathbf{h a})\end{array}$ & $\begin{array}{c}\text { Cost of cultivation } \\
\text { (Rs/ha) }\end{array}$ & $\begin{array}{c}\text { Gross return } \\
(\mathbf{R s} / \mathbf{h a})\end{array}$ & $\begin{array}{c}\text { Net return } \\
\text { (Rs/ha) }\end{array}$ & $\begin{array}{c}\text { B:C } \\
\text { ratio }\end{array}$ & $\begin{array}{c}\text { Percentage return to } \\
\text { fertilizers }\end{array}$ & $\begin{array}{c}\text { FUE on } \\
\text { economically }\end{array}$ & $\begin{array}{c}\text { Interaction impact } \\
\text { on grain yield }\end{array}$ \\
\hline MP-1142 & 51.7 & 22375 & 56870 & 35370 & $1: 2.5$ & 11.6 & 254 \\
\hline GW-273 & 52.6 & 22375 & 56870 & 36360 & $1: 2.5$ & 11.9 & 254 \\
\hline GW-322 & 56.6 & 22375 & 62260 & 49760 & $1: 2.7$ & 16.8 & 27.8 \\
\hline Sujata & 33.7 & 20000 & 43810 & 24310 & $1: 2.1$ & 7.7 & 219 \\
\hline Lok-1 & 41.5 & 20000 & 45650 & 26150 & $1: 2.2$ & 8.3 & 228 \\
\hline
\end{tabular}

$\mathrm{B}: \mathrm{C}$ ratio $=$ Benefit cost ratio, $\mathrm{FUE}=$ Fertilizers use efficiency 
Unavailability of moisture at any critical growth stage significantly reduction of dry matter accumulation its resulted very poor yield. Water stress not only affects the morphology but also severely affects the metabolism of the plant. Therefore reduce the number of grains formed per spike and kernel weight which ultimately reduced yield accorded by (Jamal et al., 1996, Asharf 1998, Denciel 2000 and Gupta et al., 2002).

\section{Economic Impact}

The cost of cultivation in demonstrations was comparatively higher (Rs 22375) as compared to farmer's practice (Rs 20500) on account of additional input provided in the demonstration. The gross returns (Rs. 56870 to 62260) and net returns (Rs 35370 to 40760) were derived from demonstrations as compared to farmer's practices (Rs 43810 to 45650) and net returns (Rs. 24310 to 26150). On average basis, the increase in net returns from adaptation of improved production module was 31.56 per cent over farmer's practice (Table 2). The benefit cost ratio was accordingly reflected to demonstrations (1:2.5 to $1: 2.7)$ and farmer's practice $(1: 2.1$ to $1: 2.2)$.

\section{Fertilizer use efficiency and percentage return to fertilizers}

Fertilizers use efficiency based on economically was found over $278 \%$ in wheat cultivar GW-322 fallowed by GW-273 and MP-1142 (254 \%) as compared to exiting variety 228 and $219 \%$ Lok-1 and Sujata (Table-3).

Because fertilizer use efficiency in crop plant is an important approach to evaluate the applied fertilizers and their role in improving in crop yield (Singh and Agrwal 2005). And maximum percentage return to fertilizers in wheat cultivar GW322 was found $16.8 \%$ fallowed by GW-273 and MP-1142 (11.9 and
$11.6 \%)$ respectively as compared to farmers traditional variety of Wheat Lok-1 and Sujata (8.3 and $7.7 \%$ ) when use of balance dose of fertilizers, due to proper availability of nutrient as per crop demand leads to improvement in grain yield and consequently the higher nutrient use efficiency similar report was found (Baligar et al., 2001, Singh and Agrwal 2005 and Singh et al., 2007)

All demonstrated varieties and existing varieties are good performing under four irrigation as schedule of wheat. But very poor increase grain yield/frequency of irrigation of existing variety of wheat Sujata as compared to water loving varieties viz GW-322, GW273 and M.P 1142.

Because existing varieties is slightly drought tolerant it is due to less response of each frequency of irrigation with balance dose of fertilizers and water loving variety have more response of each frequency of irrigation along with recommended dose of fertilizers.

Therefore, the most of the farmers should aware to irrigation scheduling of wheat crop based on availability water responsive variety. While, most of the farmers' of these districts unaware of irrigation schedule of wheat crop. In such situation maximum farmers gave two to four irrigation based on availability of water neither is necessity of water requirement it is due to wastage of irrigation water.

Under such circumstances provide information to all wheat grower, that have more irrigation capacity they can select more water and fertilizers responsive variety i.e. GW-322 GW-273 and MP-1142.

And they farmer have less irrigation capacity they can select slightly drought tolerant variety i.e. Sujata, JW-17, Amrita, Harsheeta and C-306, about exploit to yield potential of variety and water. 


\section{References}

Ambika, Tiwari O P and Shrivastava G K (2002). Response of cented rice varieties to different agro management practices. Oryza 39 (1\&2) 63-64

Ashraf M Y (1998) Yield and yield components response of wheat (Triticum aestivum L.) genotypes tinder different soil water deficit conditions. Acta Agronomy. Hung. 46:45-51

Aulakh M S and Malhi S S (2005).Interactions of nitrogen with other nutrients and water effect on crop yield and quality, nutrient use efficiency carbon sequestration and environmental pollution. Advances Agronomy 86:341409.

Baligar V C, Fageria N K and He H (2001). Nutrient use efficiency in plants. Communication of Soil Science and Plant Analysis. 32: 921-950

Behera U K, Pradhan S and Sharma A R (2007). Effect of integrated nutrient management practices on productivity of durum wheat (Triticum durum) in vertisols of central India. Indian journal of Agriculture Science 77 (10):635-638.

Bukhat N M (2005). Studies in yield and yield associated traits of wheat (Triticum aestivum L.) genotypes under drought conditions. Plant Physiology. 137: 79 1-793.

Denciel S, Kastori R, Kobiljski B, Duggan B (2000). Evaporation of' grain yield and its components in wheat cultivars and land races under near optimal and drought conditions. Euphytica 1:43-52 (Wheat. Barley and Triticale Absis. 3: 1197).

Department of Agriculture and Cooperation Friday (May 18, 2012). All-India area, production and yield of wheat along with coverage under irrigation.
Donald C M (1968). The breeding of crop ideotypes. Euphytica 17, 385-403.

Dubey Y P and Sharma S K (1996) Effect of irrigation and fertilizer on growth, yield and nutrient uptake by wheat. Indian Journal of Agronomy 41 (1): 48-51

Gupta N. K, Gupta S and Kumar A (2001). Effect of water stress on physiological attributes and their relationship with growth and yield in wheat cultivars at different growth stages. Journal of Agronomy. 86:1437-1439.

Jamal M, Nazir M S, Shah S H and Nazir A (1996). Varietal response of wheat to water stress at different growth stages and effect on grain yield, straw yield, harvest index and protein contents in grains. Rachis 15(1-2): 38-45.

Manna M C, Ghosk P K and Ganguly T K (2003)Comparative performance of four source of enriched phosphocompost and inorganic fertilizer application on yield, uptake of nutrient and biological activity of soil under soybean -wheat rotation. Food Agriculture and environment 1(2): 203-208.

Moragues M, Luis F, Moral G D, Moralejo M, Conxita R (2006).Yield formation strategies of durum wheat landraces with distinct pattern of dispersal within the Mediterranean basin II. Biomass production and allocation. Field Crops Research 95 182-193.

Pal S K, Kaur J, Thakur R, Verma U N and Sing M K (1996 a). Effect of irrigation seeding date and fertilizer on growth yield of wheat. Indian Journal of Agronomy 41 (3): 386-389.

Pal S K, Verma U N, Singh M K, Upasni R R and Thakur R (2001). Growth and yield of late sown wheat (Triticum aestivum) under different irrigation schedules. Indian journal of Agriculture Science 71(10): 664-67. 
Rahim A, Abbassi G H, Rashid M and A M, Ranjha (2007). Methods of phosphorus application and irrigation schedule influencing wheat yield. Pakistan Journal Agriculture Science. 44(3): 420-423.

Samanta S C, Biswas P, Rashid M H and Badiuzzaman (2007). Effect of cultivar and foliage purning on grain yield, grain quality and economic of aromatic rice in southern part of Bangladesh. Journal of Subtropical Agriculture Research and Development 5(3): 246250.

Sharma S N (2005). Nitrogen management in relation to wheat (Triticum aestivum) resude management in rice (Oryza sativa). Indian journal of Agriculture Science 72 (8): 449-452.

Singh R and Agarwal S K (2005). Effect of levels of farmyard manure and nitrogen fertilization on grain yield and use efficiency of nutrients in wheat (Triticum aestivum). Indian Journal of Agriculture Science. 75 (7): 408-413.

Singh G P, Sharma J B and Nagarajan S (April 2004). Improved technology for enhanced wheat production in eastern India. Indian farming (1):12-14

Singh R K, De N, Singh T K and Rai M (2007). Sulphur improves the factor productivity in pea. Vegetable Science.34 (2): 200-201

Tunio G S, Agustin M B, Nihal-Ud-dinMari and Babar M A (2002). Growth and yield of scented rice varieties under different nitrogen levels. Sarhad Journal of Agriculture 18 (3): 303-305

Wajid A, Hussain A, Maqsood M, Ahmad A and Awais M (2002). Influence of sowing date and irrigation levels on growth and grain yield of wheat. Pakistan Journal Agriculture Science. 39(1):22-24.

\section{How to cite this article:}

Saurabh Sharma, Ravindra Korake and Rohini Bharad. 2021. Effect of Balance Dose of Fertilizers and Irrigation on Yield and Yield Component of Wheat Cultivar. Int.J.Curr.Microbiol.App.Sci. 10(04): 860-868. doi: https://doi.org/10.20546/ijcmas.2021.1004.090 